\title{
Employees' Retention: Concept, Practices, and Impact Factors
}

\author{
Viviana Meirinhos, Sara Abrunhosa and Dora Martins \\ ISCAP, CEOS.PP, Polytechnic Institute of Porto, \\ Rua Jaime Lopes Amorim, 4465-004 São Mamede Infesta, Portugal
}

Correspondence should be addressed to: Viviana Meirinhos; vivianameirinhos@iscap.ipp.pt

Received date: 9 October 2017; Accepted date: 29 December 2017; Published date: 25 May 2018

Academic Editor: Lucian-Ionel Cioca

Copyright @ 2018. Viviana Meirinhos, Sara Abrunhosa and Dora Martins. Distributed under Creative Commons CC-BY 4.0

\begin{abstract}
This paper systematizes scientific knowledge on human resources retention, presenting a systematic review of the literature of the last decade. The study permitted (a) the characterization of scientific production of the last decade on the subject, (b) the identification of the main issues associated to employees' retention problematic, (c) the retention factors of employees on organizations, and (d) the more prevalent human resources management practices related to employees' retention. Results associated retention (1) to employees in general; (2) by business sector; (3) within human diversity; (4) by organizational context; (5) within international missions; (6) by roles; (7) by company size; and (8) by generation.

Organizational factors represent the factors that most affect retention, specially the good relationship with hierarchical superior and colleagues. HRM practices with most impact on retention revealed to be selection and recruitment, induction, professional development (performance management, training, career management), rewards system, organizational culture, and change management. Implementing retention practices specifically addressed to each person, organization and context is indicated to be, nonetheless, the most effective retention practice.
\end{abstract}

Keywords: Retention; human resources management; systematic literature review; good practices

\section{Introduction}

Although the employees' retention literature has been growing along the last years (Steel, Griffeth \& Hom, 2002), remains unaddressed the relationship between Human Resources Management
(HRM) practices and employees' retention (Hausknecht, Rodda \& Howard, 2009; Pinheiro, 2012; Bandura \& Lyons, 2014).

This concern is increasingly present on the agenda of organizational retention researchers given the recent growing need of linking the retention framework to other

Cite this Article as: Viviana Meirinhos, Sara Abrunhosa and Dora Martins (2018), “Employees' Retention:

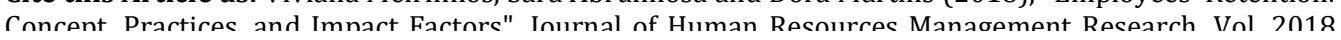


factors such as unemployment, turnover, or labor productivity. The focus on employees' retention gathers importance in both: what concerns the understanding why employees remain within the organization, and recognizing which factors underlie and are associated with human resources management (Griffeth, Hom \& Gaertner, 2000).

As referred by literature (e.g. Sullivan \& Mainiero, 2008; Holtbrügge, Friedmann \& Puck, 2010; Kaye \& Giulioni, 2016), the retention is a key factor of organizational' effectiveness, especially during recession periods, namely; the difficulty in keeping the more talented employees. Furthermore, on the one hand, recent researchers (e.g. Hausknecht, Rodda \& Howard, 2009; Snow et al., 2011; Mountford, 2013; Ramani et al., 2013; Ali, Metz \& Kulik, 2015) have shown the need of concentrating the retention analysis in different clusters, such as business activity sectors, functional positions, international assignments, work conditions as well as individual characteristics of employees. On the other hand, some authors (e.g. Rahman et al., 2010; Midtsundstad, 2011; Witter, Ha, Shengalia \& Vujicic, 2011; Mohamed et al., 2013; Hatcher, Onah, Kornik, Peacocke \& Reid, 2014; Wang \& Heyes, 2017) underline factors as job satisfaction, career advanced, self-development desire, retirement willingness, contract security, internal flexibility, and reward system satisfaction.

In line with this perspective, some recent authors (e.g. Chan \& Kuok, 2011; Clarke, 2013; Vaiman, Haslberger \& Vance, 2015; Oliveira et al., 2017) show that human resource management practices could explain the willingness to remain the organization and these authors also believe that retention management could be a critical factor for organizations around the world in the next years. According to Wright and McMahan (1992), organizations should promote different human resources management strategies for retaining their main employees during a long-time period. Finally, several studies suggest that retention management is the most important human resource process on organization return through the promotion of new capacities that promote the business competitiveness (Grant, 1996; Cegarra-Leiva, Sánchez-Vidal \& CegarraNavarro, 2012; McCracken, Currie \& Harrison, 2015), on opportunities to create new services or products (Devi, 2009), on supporting the attraction of the best applicants (Pathak, 2015), and on promoting organizations' recognition as a reference employer (Ezulike, 2012). Thus, all these factors could be a positive impact on organization image.

\section{Methods}

In order to accomplish our research goal of understanding the main factors underlying employees' retention, we developed a systematic review of literature between 2006 and 2015. This methodological option allowed us:

- To characterize the scientific production on the field of employees' retention;

- To develop a conceptual framework of employees' retention field;

- To identify the main dimensions on employees' retention addressed by scientific studies;

- To systemize all the employees' retention explanatory factors identified by scientific studies.

With this intent, we developed a sample, considering international and national (Portuguese) scientific literature. For the international sample, we considered all scientific journals with formal scientific impact, which their title included the combination of the terms "human*" and "resources*" in Boolean language $\left(\mathrm{n}^{1}=15\right)$. Our source was SciVerse Scopus and Web of Science databases (considering SCImago Journal \& Country Rank and Journal Citation Reports, both 2015 version). Access to journals was accomplished by b'on (Online Knowledge Library) between March and May 2016 (table1). 
Table 1: Human Resources' Scientific journals with impact factor within SciVerse Scopus and Web of Science

\begin{tabular}{|c|c|c|c|c|c|}
\hline \multirow{2}{*}{\multicolumn{2}{|c|}{ Databasis }} & \multicolumn{2}{|c|}{ Impact factor } & \multirow{2}{*}{ Journal Title } & \multirow{2}{*}{ Country } \\
\hline & & WoS & SVS & & \\
\hline WoS & SVS & 8 & 1 & $\begin{array}{l}\text { International Journal of Human Resource } \\
\text { Management }\end{array}$ & UK \\
\hline WoS & SVS & 9 & 2 & Journal of Human Resources & USA \\
\hline WoS & SVS & 6 & 3 & Human Resource Management Review & UK \\
\hline WoS & SVS & 4 & 4 & Human Resource Management & USA \\
\hline WoS & SVS & 7 & 5 & Human Resources for Health & UK \\
\hline WoS & SVS & 5 & 6 & Human Resource Management Journal & UK \\
\hline- & SVS & - & 7 & $\begin{array}{l}\text { Research in Personnel and Human } \\
\text { Resources Management }\end{array}$ & USA \\
\hline WoS & SVS & 2 & 8 & Human Resource Development Quarterly & USA \\
\hline WoS & SVS & 1 & 9 & Asia Pacific Journal of Human Resources & Australia \\
\hline WoS & SVS & 3 & 10 & Human Resource Development Review & USA \\
\hline- & SVS & - & 11 & Advances in Developing Human Resources & USA \\
\hline- & SVS & - & 12 & $\begin{array}{l}\text { Journal of Human Resources in Hospitality } \\
\text { and Tourism }\end{array}$ & UK \\
\hline- & SVS & - & 13 & $\begin{array}{l}\text { International Journal of Human Resources } \\
\text { Development and Management }\end{array}$ & UK \\
\hline- & SVS & - & 14 & $\begin{array}{l}\text { Human Resource Management International } \\
\text { Digest }\end{array}$ & UK \\
\hline- & SVS & - & 15 & $\begin{array}{l}\text { Research and Practice in Human Resource } \\
\text { Management }\end{array}$ & Australia \\
\hline
\end{tabular}

For the national sample, two different sources were considered: The Portuguese Open Access Scientific Repository (RCAAP) and the National General Directorate of Education and Science Statistics (DGEEC). Data was collected within these two databases in June 2016.

Documents were selected from all sources by the application of a conceptual filter: the term "retention*" was used as the keyword for collecting the documents that originated our final sample. For a more functional and specific selection, we considered both the lexical variation "retain*" and the portuguese similar "retenção*" and "reter", as well as cumulatively the "employee*" / "colaborador*" or "Staff*"/ "equipa*" or "worker*”/"trabalhador*” or "person*"/"pessoa*" or "human resource*" / "recursos humanos" or 
"HR"/"RH" or "firm*"/"empresa*", in at least one of the search fields (title or keywords). Validation criteria included (1) written in English or in Portuguese; (2) access to the article; and (3) content explicit focused on human resources retention. The final sample consisted on 189 documents.

From each document, the title, keywords, country of the first author, its institutional affiliation, number of annual citations, type of study, study sample, and main contributions were collected. Categories for studies' methodological options and for the variables studied were initially created. From the basic categorical construction, a hierarchical tree of categories and subcategories was on a second phase developed. Categorical system was validated by 3 scientific judges. This content analysis stage was held between February 2017 and May 2017 supported by NVivo software.

\section{Results}

\section{General View of Scientific Production about Human Resources' Retention}

Results show a growing trend in terms of publication numbers by year. Between 2006 and 2015, the number of scientific publications about Human Resources' retention almost tripled. Results revealed an exponential increase on scientific citation on this subject, a rise of around 149 times more citations within the analyzed decade (Figure 1).

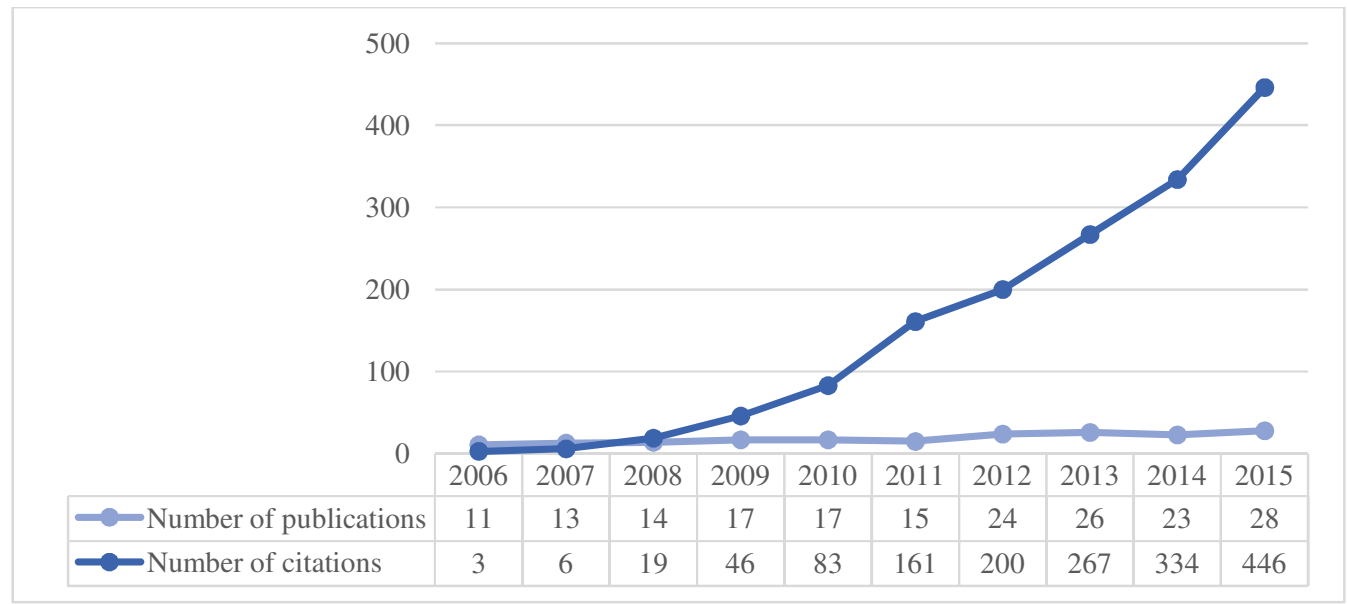

Figure 1: Number of scientific documents published per year and number of scientific documents citations

Geographically, most of scientific literature is developed by European authors (40.4\%), followed by American (36.8\%), Asian and Oceanian (both with 9.6\%) and at last African (3.8\%).

Our results demonstrate that quantitative method is dominant in people's retention studies (table 2), being applied in $64 \%$ of the articles analyzed. Thesecond place is the qualitative method with $30 \%$, and at last, the mixed method with only $6 \%$.

In order to identify the documents relevance, we analyzed the number of quotes by article. The fifteen most quoted authors represent $61.3 \%$ of the total quotes. Hausknecht (2009) is the most quoted author. 
Table 2: Top-15 most quoted authors

\begin{tabular}{|l||c|c|l|c|}
\hline \multicolumn{1}{|c}{$\begin{array}{c}\text { Main } \\
\text { Author }\end{array}$} & $\begin{array}{c}\text { Publishing } \\
\text { year }\end{array}$ & $\begin{array}{c}\text { Country of } \\
\text { main author }\end{array}$ & \multicolumn{1}{c|}{ Institutional afiliation } & $\begin{array}{c}\text { Number of } \\
\text { quotes }\end{array}$ \\
\hline Hausknecht & 2009 & USA & Cornell University, ILR School & 167 \\
\hline Henderson & 2008 & Australia & $\begin{array}{l}\text { Australian Agency for } \\
\text { International Development }\end{array}$ & 113 \\
\hline Kraimer & 2009 & USA & University of Iowa & 102 \\
\hline Manafa & 2009 & Ireland & $\begin{array}{l}\text { Centre for Global Health, Trinity } \\
\text { College, University of Dublin }\end{array}$ & 77 \\
\hline Shacklock & 2009 & Australia & Griffith University & 65 \\
\hline Sheehan & 2006 & Australia & Monash University & 51 \\
\hline Shen & 2009 & USA & $\begin{array}{l}\text { School of Management, Boston } \\
\text { University }\end{array}$ & 49 \\
\hline Rahman & 2010 & Bangladesh & $\begin{array}{l}\text { International Centre for } \\
\text { Diarrhoeal Disease Research }\end{array}$ \\
\hline Sullivan & 2008 & USA & $\begin{array}{l}\text { College of Business, Bowling } \\
\text { Green State University }\end{array}$ & 48 \\
\hline Devi & 2009 & India & KL University & 48 \\
\hline Lam & 2009 & China & $\begin{array}{l}\text { The Hong Kong Polytechnic } \\
\text { University }\end{array}$ & 46 \\
\hline Reiche & 2007 & Spain & $\begin{array}{l}\text { IESE Business School, University } \\
\text { of Navarra }\end{array}$ & 43 \\
\hline Holtbrügge & 2010 & Germany & $\begin{array}{l}\text { University of Erlangen- } \\
\text { Nuremberg }\end{array}$ & 40 \\
\hline Kaplan & 2011 & USA & Saint Louis University & 32 \\
\hline Woodruffe & 2006 & UK & Human Assets Ltd & 48 \\
\hline
\end{tabular}

In what concerns the terms more mobilized for the articles (table 3), we identified the term "retention", followed by "employee", "health", "talent", "workers", "management" and "practices".

Table 3: Main English terms used on the title of the scientific documents

\begin{tabular}{|c|c|c|c|c|}
\hline Word & Frequency(x) & $\begin{array}{r}\text { Percentage } \\
\text { (f) }\end{array}$ & $\begin{array}{r}\text { Cumulative } \\
\text { percentage } \\
\text { (Cf) }\end{array}$ & Family of words \\
\hline retention & 92 & $5,62 \%$ & $5,62 \%$ & $\begin{array}{l}\text { retention, retain, retaining, } \\
\text { retains }\end{array}$ \\
\hline employee & 50 & $3,05 \%$ & $8,67 \%$ & employee, employees \\
\hline health & 28 & $1,71 \%$ & $10,38 \%$ & Health \\
\hline talent & 26 & $1,59 \%$ & $11,97 \%$ & talent, talents \\
\hline workers & 23 & $1,40 \%$ & $13,37 \%$ & worker, workers \\
\hline management & 22 & $1,34 \%$ & $14,71 \%$ & $\begin{array}{l}\text { management, managers, } \\
\text { managing }\end{array}$ \\
\hline practices & 20 & $1,22 \%$ & $15,93 \%$ & practice, practices, practicing \\
\hline resource & 18 & $1,10 \%$ & $17,03 \%$ & resource, resources \\
\hline recruitment & 18 & $1,10 \%$ & $18,13 \%$ & $\begin{array}{l}\text { recruit, recruiting, } \\
\text { recruitment }\end{array}$ \\
\hline
\end{tabular}




\begin{tabular}{|l|r|r|r|l|}
\hline development & 13 & $0,79 \%$ & $18,92 \%$ & $\begin{array}{l}\text { developing, development, } \\
\text { developments }\end{array}$ \\
\hline human & 13 & $0,79 \%$ & $19,71 \%$ & Human \\
\hline rural & 13 & $0,79 \%$ & $20,50 \%$ & Rural \\
\hline study & 13 & $0,79 \%$ & $21,29 \%$ & Study \\
\hline job & 12 & $0,73 \%$ & $22,02 \%$ & Job \\
\hline work & 12 & $0,73 \%$ & $22,75 \%$ & work, working \\
\hline staff & 11 & $0,67 \%$ & $23,42 \%$ & Staff \\
\hline factors & 10 & $0,61 \%$ & $24,03 \%$ & factor, factors \\
\hline best & 10 & $0,61 \%$ & $24,64 \%$ & Best \\
\hline firm & 10 & $0,61 \%$ & $25,25 \%$ & firm, firms \\
\hline effect & 10 & $0,61 \%$ & $25,86 \%$ & effect, effective, effectively, \\
& & & & effects \\
\hline
\end{tabular}

Key-words, in its turn, present 423 different terms in English. Table 4 shows the most used key-words, with a cumulative frequency near $50 \%$.
"Retention" is the dominant term $(x=140)$ followed by "employee" $(\mathrm{x}=81)$, "management" (x=66), "human" ( $\mathrm{x}=44)$ and "resource" (x=63).

Table 4: Principal English terms used on the key-words of the scientific documents

\begin{tabular}{|c|c|c|c|c|}
\hline Word & $\begin{array}{r}\text { Frequency( } \\
\mathrm{x})\end{array}$ & $\begin{array}{r}\text { Percentage } \\
\text { (f) }\end{array}$ & $\begin{array}{r}\text { Cumulative } \\
\text { percentage } \\
\text { (Cf) }\end{array}$ & Family of words \\
\hline retention & 140 & $8,74 \%$ & $8,74 \%$ & retention, retaining \\
\hline employee & 81 & $5,06 \%$ & $13,80 \%$ & employee, employees \\
\hline management & 66 & $4,12 \%$ & $17,92 \%$ & $\begin{array}{l}\text { management, managers, } \\
\text { managing }\end{array}$ \\
\hline human & 64 & $4,00 \%$ & $21,92 \%$ & Human \\
\hline resource & 63 & $3,94 \%$ & $25,86 \%$ & resource, resources \\
\hline recruitment & 40 & $2,50 \%$ & $28,36 \%$ & Recruitment \\
\hline development & 36 & $2,25 \%$ & $30,61 \%$ & developing, development \\
\hline turnover & 31 & $1,94 \%$ & $32,55 \%$ & Turnover \\
\hline health & 27 & $1,69 \%$ & $34,24 \%$ & Health \\
\hline $\begin{array}{l}\text { organizationa } \\
\text { l }\end{array}$ & 27 & $1,69 \%$ & $35,93 \%$ & Organizational \\
\hline talent & 24 & $1,50 \%$ & $37,43 \%$ & talent, talents \\
\hline job & 19 & $1,19 \%$ & $38,62 \%$ & Job \\
\hline satisfaction & 18 & $1,12 \%$ & $39,74 \%$ & Satisfaction \\
\hline performance & 16 & $1,00 \%$ & $40,74 \%$ & Performance \\
\hline workers & 16 & $1,00 \%$ & $41,74 \%$ & worker, workers \\
\hline intentions & 15 & $0,94 \%$ & $42,68 \%$ & intent, intention, intentions \\
\hline training & 14 & $0,87 \%$ & $43,55 \%$ & Training \\
\hline practices & 14 & $0,87 \%$ & $44,42 \%$ & practice, practices \\
\hline work & 13 & $0,81 \%$ & $45,23 \%$ & work, working \\
\hline career & 12 & $0,75 \%$ & $45,98 \%$ & career, careers \\
\hline age & 11 & $0,69 \%$ & $46,67 \%$ & age, aged, ageing, aging \\
\hline rural & 11 & $0,69 \%$ & $47,36 \%$ & Rural \\
\hline skills & 10 & $0,62 \%$ & $47,98 \%$ & skill, skilled, skills \\
\hline
\end{tabular}




\begin{tabular}{|l|l|l|l|l|}
\hline attraction & 10 & $0,62 \%$ & $48,60 \%$ & Attraction \\
\hline awards & 10 & $0,62 \%$ & $49,22 \%$ & Awards \\
\hline culture & 10 & $0,62 \%$ & $49,84 \%$ & cultural, culture \\
\hline
\end{tabular}

\section{Contribution of Scientific Production on Retention of People}

From our sample, 8 different dimensions aroused in order to systematize the scientific production in the human resources' retention problematic: (1) employees retention $(n=83) ; \quad$ (2) by business area $(n=45) ; \quad(3)$ in human diversity scope $(n=32)$; (4) by different organizational contexts $(n=9) ; \quad(5)$ in international mission's scope $(n=9)$; (7) by organization size $(n=7) ;$ and (8) by generation $(n=5)$.

Table 5 shows that employee's retention factors are mainly organizational $(\mathrm{N}=63)$, individual $(\mathrm{N}=45)$, connected to the functions $(\mathrm{N}=24)$ and to context $(\mathrm{N}=8)$.

Table 5: Explaining factors of employee's retention

\begin{tabular}{|c|c|}
\hline $\begin{array}{l}\quad \text { Organizational Factors }(\mathrm{N}=63) \\
\text { Good relationship with hierarchical } \\
\text { superior }(\mathrm{n}=25) \\
\text { Good relationship with work colleagues } \\
(\mathrm{n}=9) \\
\text { Work conditions }(\mathrm{n}=7) \\
\text { Commitment with HRM }(\mathrm{n}=6) \\
\text { Positive external image }(\mathrm{n}=3) \\
\text { Operation market }(\mathrm{n}=3) \\
\text { Social responsibility }(\mathrm{n}=2) \\
\text { Hierarchical structure }(\mathrm{n}=2) \\
\text { Contractual stability }(\mathrm{n}=2) \\
\text { Administration }(\mathrm{n}=2) \\
\text { Favorable internal economic conjecture } \\
(\mathrm{n}=1) \\
\text { Dimension }(\mathrm{n}=1)\end{array}$ & $\begin{array}{l}\quad \text { Individual Factors }(\mathrm{N}=45) \\
\text { Effective organizational commitment }(\mathrm{n}=17) \\
\text { Work satisfaction }(\mathrm{n}=11) \\
\text { Demographic factors }(\mathrm{n}=5) \\
\text { Individual interests }(\mathrm{n}=4) \\
\text { Personality }(\mathrm{n}=3) \\
\text { Professional efficiency }(\mathrm{n}=2) \\
\text { Financial independency }(\mathrm{n}=2) \\
\text { Professional life relevance }(n=1)\end{array}$ \\
\hline \multicolumn{2}{|c|}{ RETENTION } \\
\hline $\begin{array}{l}\quad \text { Factors related to function }(\mathrm{N}=24) \\
\text { Challenge }(\mathrm{n}=6) \\
\text { Possibility of applying skills }(\mathrm{n}=5) \\
\text { Work's meaning }(\mathrm{n}=5) \\
\text { Autonomy }(\mathrm{n}=3) \\
\text { Responsibility }(\mathrm{n}=2) \\
\text { Liking the functional content of the work } \\
(\mathrm{n}=2) \\
\text { Technical knowledge of the used ITs }(\mathrm{n}=1)\end{array}$ & $\begin{array}{l}\text { Conjecture factors }(\mathrm{N}=\mathbf{8}) \\
\text { Geographical location }(n=5) \\
\text { Collective representation structures of the } \\
\text { employees }(n=1) \\
\text { Social context }(n=1) \\
\text { Unfavorable economic conjecture of the } \\
\text { country }(n=1)\end{array}$ \\
\hline
\end{tabular}

Organizational factors seem to be the most dominant group to influence retention $(\mathrm{N}=63)$, specially the good relationship with the hierarchical superior $(n=25)$ and with work colleagues $(n=9)$. Standing out are also the work conditions $(n=7)$ and the commitment of the organization with the HRM $(n=6)$. Reasons of permanency are also distributed among the individual factors of the employees $(\mathrm{N}=45)$, as an example, the effective organizational commitment $(n=17)$, the satisfaction at 
work $(n=11)$, and the demographic factors $(n=5)$. The factors connected to the functions $(\mathrm{N}=24)$ are based mainly on the challenge $(n=6)$, on the possibility of an employee applying his skills $(n=5)$ and on the meaning of the job $(n=5)$. According to the results, the context factor $(\mathrm{N}=8)$ more determining in the retention of employees is, the geographical location $(n=5)$, on the country level, region and city.
Regarding HRM practices oriented to retain workers, a total of 59 practices can be identified. On table 6 , we identify the 14 most referred practices, in which the extrinsic rewards, the opportunity of developing skills, and an attractive benefit portfolio assume first, second, and third places, respectively.

Table 6: TOP-14 of the HRM practices promoted in global retention of the employees

\begin{tabular}{|c|l|}
\hline \multicolumn{1}{|c|}{ TOP } & HRM Practices \\
\hline 1 & Extrinsic rewards (n=26) \\
\hline 2 & Opportunities to develop skills $(\mathrm{n}=18)$ \\
\hline 3 & Attractive benefit portfolio $(\mathrm{n}=17)$ \\
\hline 4 & Policy of fair rewarding (n=15) \\
\hline 5 & Diagnosis of the most suited retention practices $(\mathrm{n}=14)$ \\
\hline 6 & Retention practices adjusted to the retention of talents $(\mathrm{n}=13)$ \\
\hline 7 & Planning procedure and carrier preparation $(\mathrm{n}=13)$ \\
\hline 8 & Efficient internal communication $(\mathrm{n}=12)$ \\
\hline 9 & Balance between personal and professional life $(\mathrm{n}=12)$ \\
\hline 10 & Carrier evolution opportunities (n=11) \\
\hline 11 & Cultural cohesion development (n=11) \\
\hline 12 & Good work environment (n=11) \\
\hline 13 & Guiding the development towards the individual needs(n=10) \\
\hline 14 & Evaluation of the agreement person-organization(n=8) \\
\hline
\end{tabular}

Label: $\boldsymbol{n}$ represents the number of scientific documents that identify the shown results

Within the main HRM practices identified to improve the retention rate, are Compensation Management (e.g. extrinsic rewards), Professional Development (e.g. opportunities to develop skills), Retention Management (e.g. diagnosis of the most suited retention practices), Organizational Culture (e.g. efficient internal communication), and Recruitment and Selection (e.g. Evaluation of the agreement person-organization).

\section{Conclusion}

Results of this initial stage of the project allowed us to characterise the scientific literature on employees' retention, as well as identifying multiple explanatory factors for the retention, and the Human Resources practices converging to this goal. This preliminary analysis enabled a grounded starting point to develop solid instruments to collect data for the international comparative study, to which we invite international partners.

\section{Endnotes}

${ }^{1} \mathbf{n}$ represents the sample number

\section{References}

1. Ali, M., Metz, I. and Kulik, CT. (2015), 'Retaining a Diverse Workforce: The Impact of Gender-Focused Human Resource Management,' Human Resource Management Journal, 25(4), 580-599.

2. Bandura, RP. and Lyons, PR. (2014), 'The Art and Science of Job Satisfaction: Much of it Comes Down to Decent Management Practice,'Human Resource 
Management International Digest, 22(7), 32-35.

3. Cegarra-Leiva, D., Sánchez-Vidal, ME. and Cegarra-Navarro, JG. (2012), 'Work Life Balance and The Retention of Managers in Spanish SMEs,' The International Journal of Human Resource Management, 23(1), 91-108.

4. Chan, SH. and Kuok, OM. (2011), 'A Study of Human Resources Recruitment, Selection, and Retention Issues in The Hospitality and Tourism Industry in Macau,' Journal of Human Resources in Hospitality \& Tourism, 10(4), 421-441.

5. Clarke, E. (2007), 'Safety in Numbers (Retention),' Human Resource Management International Digest, 15(4), 44:46, accessed in https://doi.org/10.1108/hrmid.2007.0 $\underline{4415 \text { dad. } 006}$

6. Ezulike, G. (2012), 'How to Hold on to Your Key Information-Technology Specialists: ... And The True Cost of Replacing Them,'Human Resource Management International Digest, 20(4), 21-23.

7. Grant, RM. (1996), 'Toward a Knowledge-Based Theory of The Firm. Strategic management journal, 17(S2), 109-122.

8. Griffeth, RW., Hom, PW. and Gaertner, S. (2000), 'A Meta-Analysis of Antecedents And Correlates of Employee Turnover: Update, Moderator Tests, and Research Implications for The Next Millennium,' Journal of management, 26(3), 463-488.

9. Hausknecht, JP., Rodda, J. and Howard, MJ. (2009), 'Targeted Employee Retention: Performance-Based and Job-Related Differences in Reported Reasons for Staying,'Human Resource Management, 48(2), 269-288.

10.Hatcher, AM., Onah, M., Kornik, S., Peacocke, J. and Reid, S. (2014), 'Placement, Support, and Retention of Health Professionals: National, Cross-
Sectional Findings from Medical and Dental Community Service Officers in South Africa,'Human resources for health, 12:14, accessed in http://dx.doi.org/10.1186/1478-4491-

$12-14$

11.Kaye, B., and Giulioni, JW. (2012), Help Them Grow or Watch Them Go: Career Conversations Employees Want, BerrettKoehler Publishers, San Francisco.

12.

McCracken, M., Currie, D. and Harrison, J. (2016), 'Understanding Graduate Recruitment, Development and Retention for The Enhancement of Talent Management: Sharpening 'The Edge'of Graduate Talent,' The International Journal of Human Resource Management, 27(22), 2727-2752.

13.Midtsundstad, TI. (2011), 'Inclusive Workplaces and Older Employees: An Analysis of Companies' Investment in Retaining Senior Workers,' The International Journal of Human Resource Management, 22(06), 1277-1293.

14. Mohamed, AF., Singh, S., Irani, Z. and Darwish, TK. (2013), 'An Ana.lysis of Recruitment, Training and Retention Practices in Domestic and Multinational Enterprises in The Country of Brunei Darussalam,' The International Journal of Human Resource Management, 24(10), 2054-2081.

15.Mountford, H. (2013), 'I'll Take Care of You: The Use of Supportive Work Practice to Retain Older Workers,' Asia Pacific Journal of Human Resources, 51(3), 272291.

16. Oliveira, LB., Cavazotte, F. and Dunzer, RA. (2017), 'The Interactive Effects of Organizational and Leadership Career Management Support on Job Satisfaction and Turnover Intention,' The International Journal of Human Resource Management, 8:12, accessed in https://doi.org/10.1186/1478-4491-8-12

17.Pathak, AA. (2015), 'Zen Room Enhances The Workplace for Nobeltek's Women Employees: ... And Helps The 
Company to Retain Valuable Female Talent,'Human Resource Management International Digest, 23(7), 15-17.

18.Pinheiro, CAO. (2012), Gestão da Idade nas Organizações: Importância das Práticas de Recursos Humanos e Influência das Mesmas na Retenção dos Trabalhadores,' (Master's thesis). ISCTE Lisbon University Institute, Lisbon, Portugal.

19.Rahman, SM., Ali, NA., Jennings, L., Seraji, MHR., Mannan, I., Shah, R., AlMahmud, AB., Bari, S., Hossain, D., Das, MK., Baqui, AH., Arifeen, SE. and Winch, PJ. (2010), 'Factors Affecting Recruitment and Retention of Community Health Workers in a Newborn Care Intervention in Bangladesh, 'Human Resources for Health, 8:12, accessed in https://doi.org/10.1186/1478-4491-8-12

20.Ramani, S., Rao, KD., Ryan, M., Vujicic, M. and Berman, P. (2013), 'For More Than Love or Money: Attitudes of Student and In-Service Health Workers Towards Rural Service in India.Human Resources for Health, 21(1), 11:58

21.Snow, RC., Asabir, K., Mutumba, M., Koomson, E., Gyan, K., Dzodzomenyo, M., Kruk, M. and Kwansah, J. (2011), 'Key Factors Leading to Reduced Recruitment and Retention of Health Professionals in Remote Areas of Ghana: A Qualitative Study and Proposed Policy Solutions,' Human Resources for Health, 9:13. Doi: 10.1186/1478-4491-913.
22.Steel, RP., Griffeth, RW. and Hom, PW. (2002), 'Practical Retention Policy for The Practical Manager. The Academy of Management Executive, 16(2), 149-162.

23.Sullivan, SE. and Mainiero, L. (2008), 'Using The Kaleidoscope Career Model to Understand The Changing Patterns of Women's Careers: Designing HRD Programs That Attract and Retain Women,' Advances in Developing Human Resources, 10(1), 32-49.

24.Vaiman, V., Haslberger, A. and Vance, CM. (2015), 'Recognizing the Important Role of Self-Initiated Expatriates in Effective Global Talent Management,' Human Resource Management Review, 25(3), 280-286.

25.Wang, W. and Heyes, J. (2017), 'Flexibility, Labour Retention and Productivity in The EU,' The International Journal of Human Resource Management, DOI: 10.1080/09585192.2016.1277370, accessed in http://dx.doi.org/10.1080/09585192.201 6.1277370

26.Witter, S., Ha, BTT., Shengalia, B. and Vujicic, M. (2011), 'Understanding The 'Four Directions of Travel': Qualitative Research into The Factors Affecting Recruitment and Retention of Doctors in Rural Vietnam,'Human Resources for Health, 9:20.

27.Wright, PM. and McMahan, GC. (1992), Theoretical Perspectives for Strategic Human Resource Management, Journal of management, 18(2), 295-320. 